\title{
English Education Development Effort With A Communicative Language Teaching (CLT) Approach Method
}

\author{
Ilham Ramadhan ${ }^{1}$, Lintang Shaban Nanda ${ }^{2 *}$, Putri Risma Alfiona ${ }^{3}$, Wardah Syaima' Nejed ${ }^{4}$ \\ ${ }^{1,4}$ Kurikulum dan Teknologi Pendidikan, Fakultas Ilmu Pendidikan, Universitas Negeri Semarang, \\ Semarang, Indonesia \\ Email: ${ }^{1}$ ilhamr170803@gmail.com
}

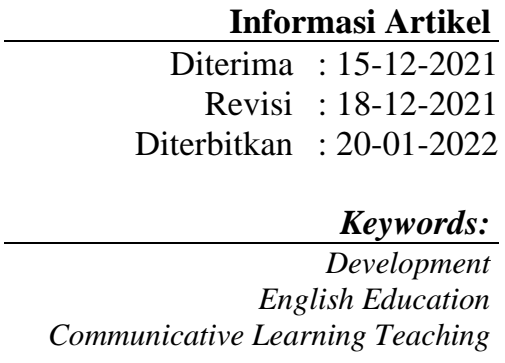

Abstract

The implementation of foreign language learning in Indonesia is an effort to develop the education of the Indonesian nation to be able to absorb and follow the development of science and technology in the world, as well as a way to enter the global society. The use of English as a foreign language in Indonesian education aims to improve the quality of students so that they can compete in the international realm. In learning English, speaking ability is a very important aspect, especially for teachers. Implementation in the classroom, the teacher is expected to be a good facilitator and motivator so that students have an increasing enthusiasm for learning. One of the teaching methods that can be applied is Communicative Language Teaching (CLT). The development of English education can be done using the Communicative Learning Teaching (CLT) method where the concept used is through Communicative Competence. The method of writing this article uses qualitative research methods with a literature review approach. The result of this research is the author's presentation of the developmental efforts that can be made by teachers and students in developing English education.

\section{INTRODUCTION}

Language has a very important role in human life. Language serves as a communication tool to convey messages in social interaction. A language is a tool used by humans to convey information, ideas, and ideas. Language is a product of human culture whose life is always dynamic, creative, and tends not to be static (see Helmanita, 2013). To have the ability to convey this communication, language learning should be directed to equip students with communicative abilities.

English is the most important language in the world. The number of speakers spreads all over the world, either as a first language (first language), second language (second language), or foreign language (foreign language). In Indonesia itself, the position of English is as a foreign language. English is the most important foreign language learned in Indonesia. The term foreign language in the field of language teaching is different from the second language. A foreign language is a language that is not used as a means of communication in the particular country where it is taught. Meanwhile, a second language is a language that is not the main language but is one of the languages used in general in a country. Meanwhile, a foreign language is usually taught as one of the subjects in school with the aim of basic communication and mastering 4 language skills (listening, reading, and writing). write, speak) in that language within the limits certain. In Indonesia, the policy of teaching English as a foreign language changes over time and changes in policies that are mostly influenced by economics and politics.

In Indonesia itself, the position of English is as a foreign language. English is the most important foreign language learned in Indonesia. English in Indonesia is generally taught as a foreign language. This proves that English is very widely used. Therefore, learning and mastering English is a necessity, if we don't want to say it is a must. In Indonesia, learning English is still very difficult for most people, and sometimes even scary for some. In Indonesia, English is only learned at school but is not used in everyday life. That's why English in Indonesia is generally taught as a foreign language. The term 'foreign 
language' in the field of language teaching is different from 'second language'. A foreign language is a language that is not used as a means of communication in a particular country where the language is taught. a second language is a language that is not the main language but is one of the languages used in general in a country, this is highly recommended because knowledge of English for the development of an individual in the country

Indonesia is inevitable. Like it or not, this subject is something that every Indonesian need to learn. Learning and increasing the frequency and scope of English, does not mean that we as Indonesians ignore Indonesian and regional languages. The development of Indonesian to become an international language along with the development of regional languages of which about 500 are threatened with extinction does not at all contradict the mastery of English. Developing Indonesian and regional languages simultaneously by using English will make the Indonesian people a multilingual society such as Malaysia, Singapore, and several European, African, and Middle Eastern countries.

\section{METHOD}

The method of writing this article uses qualitative research methods with a literature review approach. Qualitative research is library research that uses books and other literature as the main object, qualitative research is "a research procedure that produces descriptive data in the form of written or spoken words from people and observable behavior." The research stages were carried out starting from article collection, article reduction, article display, discussion, and conclusion. The source of research data is in the form of national journal articles in the last 10 years.

\section{RESULT AND DISCUSION}

English education is one of the most important subjects. Various ways have been carried out by the Ministry of National Education (Kemendiknas), as a breakthrough to achieve the target of optimal student English mastery. The 1994 curriculum which replaced the 2004 curriculum and was later refined into the 2006 curriculum requires learning to develop 4 language skills, namely: listening (listening), reading (reading), speaking (speaking), and writing (writing). The learning orientation of the four skills aims to improve students' abilities.

\section{Definition of Development}

According to the Law of the Republic of Indonesia, number 18 of 2002 Development is a scientific and technological activity that aims to utilize proven scientific theories and theories to improve the functions, benefits, and applications of existing science and technology or produce new technologies.

Development is a process used to develop and validate educational products. This research follows a cyclical step. This research step or development process consists of a study of the research findings of the product to be developed, developing a product based on these findings, conducting field trials according to the setting in which the product will be used, and revising the results of the field test (Punaji Setyosari, 2008). 2013: 222-223)

In essence, development is an educational effort both formal and non-formal which is carried out consciously, planned, directed, regularly, and responsibly in the context of introducing, growing, guiding, developing a personality basis that is balanced, intact, in harmony, knowledge, skills according to talent. , desire and ability as a provision on one's initiative to add, improve, develop oneself towards the achievement of optimal human dignity, quality and ability and an independent personality (Iskandar Wiryokusumo in Afrilianasari; 2014).

Modern times like today, where everything has developed rapidly. Likewise, humans are required to be able to have the ability to keep up with the developments of the modern era, one of which is by developing the ability to speak English. According to Chaer (2013: 177), English is the main international language that is the lingua franca of all nations in the world, so if we want to enter the international arena, we must master English well. So, by being able to speak English we can easily communicate with other people around the world. It would be better if Indonesian sons and daughters mastered a foreign language, but also had to master good Indonesian as well.

The use of English in Indonesian society is increasing. This happens because people are influenced by technology and social media. One of them is the number of English-language films that are 
popular among the public. The film influenced people to use English, some even mixed it with Indonesian.

Vocabulary from English is also widely absorbed into Indonesian. As the word cartoon in Indonesian becomes a cartoon; aquarium into an aquarium; coupon becomes a coupon; and much more. This can increase vocabulary in Indonesian. Absorbed words from various languages can be found in the PUEBI (General Guidelines for Indonesian Spelling).

\section{History of the Development of English in Indonesia}

Teaching English in Indonesia has started in the Dutch colonial era. However, the teaching of English was abolished by the Japanese occupation government. The abolition was part of the revision of the education system held by the Dutch colonial government. After Indonesia proclaimed independence on August 17, 1945, the teaching of English began to be reintroduced.

The development of learning English was seen after Mr. Wachendorf as the first person to serve as the Head of the Inspectorate of the Center for English Teaching at the Ministry of Education, stated that English is the first foreign language that must be taught in secondary schools in Indonesia. According to Wachendrof, the aim of teaching English is to equip students with "working knowledge of English". The teaching of English in Indonesia is also strengthened by the Decree of the Minister of Education and Culture, No. 096/1967, which is still valid today.

Since then, changes in ministers, curriculum, political, economic, and educational developments have continued to color the development of teaching English as a foreign language in Indonesia. Starting from the teaching system where students are required to memorize hundreds of words and their meanings in a certain time, master grammar, then change to an English orientation for communication, to the issue of teaching English for children today.

\section{The role of English in the learning process}

Language and education are two things that are closely related. Language is the main tool of education. On the other hand, education contributes its procurement to developing and fostering language. Both are important things that are intertwined in developing and improving every aspect of people's lives.

Besides Indonesian, there is also English as a supporting language in the learning process. It is undeniable that English is no less important for the development of science. In our current life, English has become a second language which is an international language. Along with the development of technology and the times, everyone needs to learn English. It can be said that by learning English, we can compete with others in this increasingly sophisticated era. In that era, everyone is required to be able to master science and technology, full of a competitive atmosphere in various fields. The Indonesian government included English as the first foreign language used in Indonesia. English is included in the curriculum and is an important subject in elementary, junior, and senior high schools so that it has a great opportunity to be used as the language of instruction in several schools in Indonesia

Because English is an international language, it will certainly be a requirement if the Indonesian people want to study abroad or take business trips abroad, it has become mandatory to be able to speak English well. To support this, there are many institutions and educational institutions that use English as a language for daily communication

In addition, some schools organize English extra-curricular activities such as English Club, which allows every student to communicate freely in English. English teachers in schools are starting to get used to using English as an introduction in the teaching and learning process (KBM), although not entirely. Of course, this has a very good goal, namely so that students can act in speaking English in listening and reading skills (receptive skills) or writing and speaking (productive skills), starting from basic, skilled and advanced levels. . This is certainly not to eliminate Indonesian from society but to make English a supporter for the development of the Indonesian state itself.

\section{The State of English Teaching in Indonesia}

Indonesian people's English proficiency is still relatively low when compared to other countries in Southeast Asia, if this is allowed then Indonesia will be left behind from the times. World Bank data 
shows that the biggest gap that the local workforce has is $44 \%$ in the use of English. Based on research conducted by the world education institution, EF (English First) announced the first comprehensive report on the EF English Proficiency Index (EF EPI) in 44 countries with English proficiency in Indonesia.

Indonesia is very low at 34th under Singapore, while Malaysia is in 9th place. The EF EPI is the first index to compare adult English proficiency in different countries. This index uses unique test data (specific methodology) on more than two million people in 44 countries, who used free online tests over three years (2007-2009) (Fisher, 2011).

Many Indonesian people complain about learning English, such as being difficult to learn or too complicated, feeling that English is not too important, or for old people, it is too late to learn English. This is coupled with the high cost of language laboratory enrichment in schools, which of course costs quite a bit of money, especially with the implementation of the TOEFL/Toeic test at the SMA/SMK level. In addition, English lessons that get less attention at the elementary school level because they are included in local content are not mandatory in the implementation of the 2013 curriculum, which is also the reason for the difficulty of developing English in Indonesia.

Entering the era of globalization which requires every individual to prepare reliable resources, especially in the field of science and technology. Many companies or government agencies require someone to be proficient in English. Many job application advertisements include applicants who speak English. English must be mastered because it is an international language. This language is used to communicate and interact in the exchange of science and technology and cooperation in the business world with entrepreneurs from other countries. To be able to master technology well, adequate knowledge is needed so that we can use it in facing the demands of a global world that is full of competition. In this case, the role of English is needed both in mastering technology and interacting directly. As a means of global communication, English should be actively mastered both orally and in writing. As the world's social language, English is not only a global communication medium, English is also an academic need whose mastery is in the language aspect.

Someone who has good English skills is more considered in the world of work because currently, Indonesia is starting to enter the global market which of course requires a lot of workers who can speak English well. Apart from the Indonesian people who are still low in mastering English, now English has succeeded in entering and being accepted by the Indonesian people, especially the millennial generation. Many found in social media that the use of English is more prominent when compared to the use of Indonesian itself. Some think that the more English vocabulary they use, the cooler a person looks.

English ability people in Indonesia are recognized as still very at least World Bank data shows that the greatest energy possessed by local work is 44\% language use English. The English Proficiency Index (EPI) released by Education First (EF) provides data that the results of the study of 70 Englishspeaking country level adults in Indonesia are in a position 32nd behind Singapore and Malaysia which have a high level of proficiency (advanced). This shows that the country Indonesia is still far behind the country's neighbor. Many reasons complained by Indonesian people in learning the language English, such as difficulty to learn or too complicated, feel English is not very important, or for people who are old already late to learn English. Many companies or institutions require someone to be proficient in English. In application advertisements, too many applicants are fluent in English. English must be mastered as an international language. this language as well as universities. With things This can, of course, be used as capital for the development of English in Indonesia because of the community's English ability, Indonesia is still relatively low compared to other countries in Asia Southeast, if this is allowed then Indonesia will lag behind the development era. The development of today's era is very rapidly followed by globalization and a global economy that requires every individual to be able to speak English well.

\section{The Purpose of Teaching English in Schools}

In the view of modern learning, students are no longer considered as objects of learning, and teachers are no longer considered sources of information, but both collaborate in the process of teaching and learning interactions in the classroom to achieve learning objectives. The role of students in learning according to Sanjaya that the role of students in contextual learning is; (1) Students are seen as developing individuals. Their learning ability will be largely determined by their level of development and experience. (2) Every student tends to learn new and challenging things. Therefore learning for them is solving every challenging problem. (3) Learning for them, the process of looking for links or connections between new things and things that are already known. (4) Learning for students, the process 
of perfecting existing schemes (assimilation), or the process of forming new schemes. Thus in the process, students as the central point of learning, are more active in finding and solving learning problems, and the teacher's task is to help students who have difficulties, and difficulties in understanding and solving problems.

The Purpose of Teaching English in SchoolsBased on the Graduate Competency Standards, students can understand the text interpersonal and transactional both formal and informal texts. On the other hand, In the 2013 curriculum, the teaching and learning process is carried out thematically. integrative and requires authentic learning resources. Eyes teaching goals English lessons in the current curriculum include: (1) Develop the ability to communicate in the language both orally and write. These abilities include listening, speaking, (speaking), reading (reading), and writing (writing); (2) Cultivating awareness of the nature and importance of English as a language foreign to be the main tool of learning; (3) developing understanding linkage between language and culture and broaden cultural horizons

\section{Communicative Learning Teaching Method (CLT)}

Communicative Language Teaching (CLT) is an approach in teaching a foreign language or a second language that emphasizes interaction, both as a means and as a goal of learning a foreign language. In applying this approach, language learning is not only determined by how to teach certain aspects of the language but also seeks various exercises that provide opportunities for students to improve their language skills (Harmer, 2001).

CLT changes the teacher-centered learning process into student-centered learning, where students have the freedom to move and discuss all available materials. Furthermore, Savignon (1991) suggests that active communication will not occur if students only memorize sentence patterns so that students must be trained to seek and find the meaning of the sentences they are studying. The concept of CLT language learning focuses on the function and potential of a language (Richards and Rodgers, 2007).

The Communicative Language Teaching learning method or also known as the Communicative Approach is a learning method that emphasizes learning on student interaction as the ultimate goal of learning. The CLT learning method is a series of teaching steps that focus on communicative language learning.

In its application, the CLT method consists of five things, namely: 1) appropriateness, namely the application of language according to the context of its use, both in terms of formality and conversational situations; 2) message focus, namely understanding the meaning of language to the actual meaning where the transfer of information occurs in the learning process; 3) psycholinguistic processing, namely the use of cognitive abilities and other processes in language acquisition; 4) risk-taking, namely the use of various communication strategies where students can learn from the language mistakes they have made; and 5) free practice, namely the use of various basic language skills in language learning.

The main purpose of CLT is to apply the theoretical perspective that has been obtained by students by emphasizing communication skills as the main goal of language learning. The intended communication ability is when, where, how, and with whom the communication is carried out (Hymes, 2000).

\section{English Education Development Efforts through the method CLT}

The development of language skills is related to the development of speech, the more people can speak, the richer their language skills, the richer the language skills make children more confident to speak (Bjorklund, 2005). The language theory underlying CLT views "language" as "communication." Therefore, the main goal of CLT is to develop communicative competence (Richards and Rodgers, 2007). There are several models of communication competence that can be used as a basis for teaching. The model was first proposed by Canale and Swain (1980) and described in more detail by Canale (1983). Four components of communication competence are proposed in this model as follows. 1. Grammatical (Grammar). This includes knowledge of language codes (grammar, vocabulary, pronunciation, writing, etc.).2. Sociolinguistics (Sociolinguistics)

This is the mastery of the socio-cultural code of language use (appropriate use of vocabulary, registers, politeness, and style in certain contexts). 3. Discourse (Discourse) The ability to combine the structure of language into a cohesive reading (eg speech and poetry). 4. Strategic (Strategy) Knowledge of 
communication strategies, both verbal and nonverbal, that help students overcome communication problems and make communication more efficient.

\section{Teacher's Role in Communicative Language Teaching Method}

Several roles are assumed for teachers in the application of Communicative Language Teaching methods, the importance of certain roles determined by the CLT view is adopted.

The teacher has two main roles: the first role is to facilitate the communication process between all participants in the class, and between participants with various activities and texts. The second role is to act as an independent participant in the teaching-learning group. This last role is closely related to the goals of the first role and arises from it. This role implies a set of secondary roles for the teacher; first, as a resource organizer and as a resource itself, secondly as a guide in class procedures and activities. The third role for teachers is that of researchers and students, with many contributions in terms of appropriate knowledge and abilities, experience, and observable nature of learning and organizational capacity.

Implementation of the use of CLT in learning

Currently, classroom activities require many changes and innovations in new methods as an effort to improve the learning process. while still being designed to focus on completing tasks mediated through language or involving negotiating information and sharing information. In its application in the classroom, CLT uses every activity that involves authentic interactions, both between teachers and students and between students and students. There are two forms of activities in the CLT class, including:

\section{Functional communication activities}

Activities that aim to develop certain language skills and functions, but still involve communication.

Example:

- How to express opinions

- How to submit criticism and suggestions

- How to ask the time

- How to ask and give directions, etc.

\section{Social interaction activities}

Activities that emphasize the use of the language

Example:

\section{- Conversations and discussions,}

The whole class participates in discussions on various issues. Each student is allowed to convey the results of their observations and reactions. The discussion is guided by the teacher either by applying English as an opening, or closing to develop an understanding of problems and English language skills, which in turn fosters the new understanding that is useful for observing and responding to other situations in everyday life.

\section{- Dialogue}

Dialogue in the process of learning English is a model of conversation. Dialogue is a short conversation that aims to make it easy for students to memorize both inside and outside the classroom. Dialogues are usually written in the form of conversations to practice students' English pronunciation skills. The dialogue made is attempted to approach the use of real and reasonable language.

Teachers and students conduct dialogue or light conversations that can be applied in everyday life so that students easily understand and can apply these conversations at home. 


\section{- Roleplay (role play).}

Role-Playing is also known as sociodrama. Meanwhile, Adam Blatner, M.D, 2009, mentions Roleplaying, a derivative of a sociodrama, is a method for exploring the issues involved in complex social situations. Sociodrama dramatizes behavior about social problems.

Through role-playing, students can practice their English conversation skills in the form of creating historical events, creating actual events, or events that may appear in the future. The teacher monitors and observes, and can also correct errors in its application.

The application of the role-playing method contributes greatly to the improvement of social skills and speaking skills of students, this can be proven from the personal attitude of students who were hesitant when playing roles and interacting and talking already. do not hesitate to play their role, students can make eye contact as well as respond to conversations, participate in group activities and students can speak freely.

\section{- Information gap activities}

According to Hammer (2007) in How to Teach English IGA is an activity in which students get different information on the same topic and must share that information (usually without seeing what information their partner gets) so that they can get all the information they need to learn. complete their task.

The success of foreign language learning requires a positive response from students. Learning will be effective if students are happy and not depressed or nervous. Previously, only a few students enjoyed learning to speak English, the application of IGA in the learning process made students happy to learn to speak English. This level of enjoyment certainly has an impact on improving student learning and performance. Confidence is very important in promoting language fluency in learners. students will like IGA-based learning, for example with implementation in learning, namely the use of two slightly different images, where students are asked to compare them to find the differences without looking. The focus of students' attention is on how the task or game can be completed, or on its meaning, and not on the form of the language. That way, students will focus on completing assignments rather than learning the language, so students will not be afraid to make mistakes.

\section{- Games}

By using games in learning, teachers can provide stimulus to three important parts of learning, namely emotional, intellectual and psychomotor.

Games are currently a learning practice that is currently being loved, either in the form of real games or in the form of applications. The application of educational games began with the development of video games very rapidly and made them effective, interactive, and developed in industrial companies. Seeing the popularity of video games, educators think that game design components can be used as an introduction to learning materials and can be applied to the educational curriculum. Criteria Games must have an interactive interface design and contain elements of fun (Hurd and Jenuings, 2009).

\section{- Pair work}

Pair work or paired activities can be applied by teachers with questions and answers between students, which can create an atmosphere of HSTT (high student talking time), and LTT (low teacher talking time), which means giving more opportunities to practice speaking to students (not dominated by teachers). ), and thus the teacher only functions as a facilitator, giver of instructions, and controller of pronunciation, intonation, and accuracy of wording.

The existence of pair work in the learning process can make students free to express their opinions or feelings because they are free to talk to their friends. By using pair work, students will have the opportunity to speak freely in pairs class with friends. Sometimes, students are shy to talk to their teacher, but if they talk with their friends they will be free to express their opinion. McDonough and Shaw (1993:227) say that "work pairs need a little bit of organization on the part of the teacher" and it can be activated in most classrooms simply by having students work with the person sitting next to them. This means that students can be active because they are not studying alone, but they study together with their friends. They have a partner to communicate with within class. 


\section{Advantages and Disadvantages of the Communicative Language Teaching (CLT) method}

Advantages of Teaching Communicative Languages The application of CLT has brought many advantages to Teaching English as a foreign/second language. Some experts suggest some of the main advantages of CLT as follows: a) Motivates students to improve their ability to use English on their own because it emphasizes fluency in the target language. The learning process allows students to ride and develop their ideas about what they will do and express. This allows them to increase their selfconfidence and enjoy speaking more 14 . b) CLT focuses on and aims at communicative competence. Thus, enabling students to apply language in communicative situations to meet their needs in real-life communication c) The main part of the learning process is not teacher-centered for this reason illustrates that CLT classrooms have moved from teacher-centered to learner-centered. In other words, more time is spent by the learner than the teacher's role only to facilitate the learning process. For this reason, learners must practice and communicate quite a lot in CLT classes to achieve communicative competence. The positive impact of the English language is being able to follow developments in the world. English is an international language, so it is easier to follow developments in the world by being able to use English. English, which is a foreign language in Indonesia, has a big role for Indonesia itself. The development of the Indonesian language which will follow international trade channels is smooth. The existence of English (foreign language) as an international language, Indonesian education from elementary school to university has curriculum and lessons about English. This is done so that Indonesian human resources can take part in globalizing the world.

Disadvantages of Communicative Language Teaching include a) This method prioritizes meaning and usage rules rather than grammar and structural rules. In other words, there is less emphasis on correcting pronunciation and grammatical errors. it is due to too much attention to meaning at the expense of form. it is believed that with CLT there is a danger of focusing too much on oral skills and less emphasis is placed on reading and writing skills b) The CLT approach focuses on fluency but not accuracy in grammar and pronunciation c) The CLT approach is great for intermediate and advanced students, but for beginners, some controlled practice is required Students with low proficiency levels in the target language may find it difficult to participate in spoken communicative activities and, if the exam is used by a grammar-based institution, communicative fluency may not be appropriated) Teacher monitoring abilities should be excellent. Despite the best efforts of teachers, classroom activities are not truly real life and it may be difficult to develop honest and authentic use of language and to facilitate real interactions. Furthermore, the main principle underlying this method is its emphasis on the needs and interests of learners. This implies that more effort is expected that each teacher should modify the syllabus to suit the needs of the learners. e) CLT is sometimes difficult to implement in EFL classrooms due to a lack of resources and tools such as authentic materials and native speaker teachers and large class sizes. In addition, there are no suitable classrooms that can allow for group painting activities and teaching aids and materials. The negative impact of using English is that it can shift Indonesian if people prefer English. Subiyatningsih (2016) found the notion that Indonesian is easy, so it does not need to be studied specifically. For them, in language, it is more important to be communicative even though it is not by spelling rules. With this assumption in society, the Indonesian language is increasingly threatened and the sense of nationalism in Indonesian is reduced. The solution so that the attitude of Indonesian-language nationalism does not decrease is when people use English more, then directly or indirectly the attitude of nationalism towards Indonesian/regional languages will gradually decrease. In addition, another negative influence is the way the language is used which is currently popular in all circles is the use of mixed language. Indonesian combined with foreign languages. Many children today feel more confident and slang when using this mixed language.

\section{CONCLUSION}

Language and science are inseparable units. With language, all knowledge created and discovered can be disseminated to others as a way to promote the welfare and sustainability of a better human life. English as a foreign language is a complementary language and has an important position in the learning process in Indonesia. Being proficient in English, students can improve their quality and can compete internationally. Therefore, the development of English language education cannot be separated from increasing the capacity of teachers and improving learning models for students so that the learning process can develop and the quality of English language education in Indonesia increases. Based on some of the descriptions above, Communicative Language Teaching (CLT) is a very effective method when used as a method in the current English teaching and learning process, this is based on the communication 
skills obtained by students not only limited to knowledge, students will be motivated and feel that something they have learned can be useful and used in language.

\section{REFERENCES}

[1] Afifah, Riana. (2012). Again, elementary English is not abolished. https://edukasi.kompas.com/read/2012/11/13/11331821/ Edukasi News. (accessed December 06, 2021)

[2] Alamri, W. A. (2018). Communicative language teaching: Possible alternative approaches to clt and teaching contexts. English Language Teaching, 11(10), 132-138.

[3] Alfarisy, F. (2021). English Language Learning Policy in Indonesia in the Perspective of Formation of Global Citizens with Intercultural Competence. Scientific Journal of the Educational Profession, 6(3), 303-313.

[4] Augustine, Julia. (2015). "The position of English as the language of instruction in education." Deixis 3.04: 354364.

[5] Bill Fisher, (2011). President of the online division of EF Englishtown in Jakarta, Compas.Com on http://edukasi.kompas.com/read/2011/09/26/21320318/Kecepatan.Bahasa.English.di.Indonesia.Low.

[6] Budiarso, Ivan. (2019). Analysis of the Communicative Language Teaching (CLT) Method on the English speaking skills of teachers of SMK and SMP Islam Mandiri Bojong Gede Bogor, Vol.3 (3). Pg.241

[7] Curriculum. (2017). Curriculum 2013 high school competency standards and Madrasah Aliyah: specific guidelines for English subjects. Jakarta: Dharma Bhakti

[8] Cynthia, A. R., \& Cahyana, A. (2014). The Effectiveness of the Communicative Language Teaching (CLT) Method in Improving the English Communication Skills of Course Participants at PQEC Institute. Journal of Out-of-school Education, 10(2).

[9] Febriyanti, R.H. (2017). THE USE OF COMMUNICATIVE LANGUAGE TEACHING METHODS IN ENGLISH TEACHING TO TUTOR TEACHERS IN LEARNING GUIDELINES. Factor: Scientific Journal of Education, Vol.4

[10] Fitriyani, F, Hasbi, M, Veda, S (2019). Teaching communicative English. National Seminar on Community Service.

[11] Irianti, Yani (2020) Proficient in Speaking through pair works dialogue, radar Semarang article, accessed on 12 December 2021, on https://radarsemarang.jawapos.com/article/untukmu-guruku/2020/03/06/mahirspeaking-via -pair-work-dialogue/

[12] Iskandar Wiryokusumo in Afriliana Sari. (2014) Development Theory, Surabaya

[13] Ismukoco. 2012. Information Gap Activities to Improve English Speaking Skills. Accessed on Sunday, December 12, 2021. From: http://smoothmirror.blogspot.co.id/2012/07/classroom-action-research-car.html

[14] Kusumawati, Tri I. 2018. The Role of Language Indonesia in the Era of Globalization. Journal of Nizhamiyah, $8(2), 68-77$.

[15] Maulana, Muhammad Sidqi (2017). GAME IMPLEMENTATION TO IMPROVE LEARNING OUTCOMES ON RESOURCES NATURE IN SMP NEGERI 2 PEKALONGAN. Semarang State University. accessed on 12 December 2021.

[16] Ningsih, Ayu Novita. The use of Indonesian and English in supporting science in the Global era. Accessed on December 03, 2021, from FKIP Universitas Negeri Sebelas Maret Surakarta

[17] Nisa, K \& Imam Suyitno. 2017. Errors in the Use of Indonesian in Student Translation Texts. Journal of Basindo, 1(1), 2017

[18] Nita, S. A. dan Syafei, A. F. R. (2012). INVOLVING AUDIO-LINGUAL METHOD (ALM) AND COMMUNICATIVE LANGUAGE TEACHING (CLT) IN TEACHING SPEAKING SKILLS AT JUNIOR HIGH SCHOOL. Journal of English Language Teaching, Vol.1 No.1

[19] Nurdina, Devy Emsa, Sudirman Sudirman, Huzairin Huzairin. (2014). THE IMPLEMENTATION OF PAIR WORK IN TEACHING SPEAKING. UNILA Journal Of English Teaching, Vol.3 (4)

[20] Panggabean, Himpun. (2016). "The urgency and position of English in Indonesia." Indonesian Methodist University, Medan.

[21] Pedagogia (PT. Pustaka Insan Madani, Member of Ikapi)

[22] Punaji Setyosari.2013. Educational Research and Development Methods. Jakarta: Kencana Prenada Media Group.

[23] Rahmatillah, K. (2021). LEARNING ENGLISH THROUGH COMMUNICATIVE LANGUAGE TEACHING (CLT) APPROACH. Journal of Character Education Society, Vol. 4, No. 1, 1-10.

[24] Rambe, Sojuangon (2017). Communicative Language Teaching. English Education, Vol.05(2), pg.54

[25] Rondiya, A. A. Wardani, N.E. \& Saddhono, K. 2017. Literature Learning through Language and Culture to Improve National Character Education in the MEA (ASEAN Economic Community) Era. The 1st Education and Language International Conference Proceedings Center for International Language Development of Unissula. 1 (1). 141-147.

[26] Safrina Fauziyah Rashor. 2013. Foreign Languages Support the Success of AEC 2015. Jakarta.

[27] Sari, Linda, and Zuliana Lestari. (2019) "Improving Students' English Speaking Ability in Facing the Revolutionary Era 4.0." Proceedings of the National Seminar on the Postgraduate Program at PGRI Palembang University. Vol. 12. No. 01

[28] Siska, Yulia. "The application of role-playing methods in improving social skills and speaking skills of early childhood." J. Educ 1.1 (2011): 31-37. 
[29] Syahputra Idham (January, 2004). Learning English as a Foreign Language Strategy in improving students' language skills. Journal of Religious Social Research, Vol.17(1). accessed on 03 December 2021.

[30] Syahputra, Idham. (2015) "Strategies for learning English as a foreign language in improving students' language skills." Kutubkhanah 17.1: 127-145.

[31] Uzer, et al. (2019). Socialization of the Communicative Language Teaching (CLT) Method to Improve Speaking Skills using Multimedia devices at SMAN 1 Pampang OKI, Journal of PKM Educational Sciences, Vol.2, from PGRI University Lembang.

[32] Waduwu, Byslina. (2016). The importance of learning English at school. News Journal : 50

[33] Widagdo, A. (2018). IMPLEMENTATION OF CLT LEARNING MODEL TO IMPROVE ACTIVE SPEAKING ABILITY IN ENGLISH BASED ON CHARACTER VALUES. Magistra, Vol.9, No. 2.

[34] Wijaya, Iriany Kesuma. (2015). "English Learning in Elementary School." Ark: Journal of Language and Literature Education 14.2: 120-128. 